\title{
Composition of Ingredients in Syubhah Semi Processed Food, Trust and Purchase Behavior - A Conceptual Framework
}

\author{
Reezlin A. Rahman \\ Sungai Petani Community College \\ Rahanita A. Rahman \\ Sik Community College \\ Mohd Salehuddin Mohd Zahari \\ Universiti Teknologi Mara, Puncak Alam
}

\begin{abstract}
The paper aims to reviews the growing dimension of Halal food industry, whereby consumers nowdays tend to purchase Syubhah semi processed food due to the lack of knowledge on composition of ingredients, wholesomeness, labeling and certification. An extensive review of the current literature reveals that limited holistic studies on Syubhah semi processed food exist. This study, therefore, aims to fill this gap by proposing a conceptual framework for syubhah semi processed food. This study develops a conceptual framework explaining consumer intention formation by underpinned with the theory of planned behavior which consist of attitude toward behavior, subjective norm, perceived behavioral control, intention and behavior. This study not only has implications for future research, but also provides useful information for academician and practitioners in the Halal food industries.
\end{abstract}

Key words: Halal, Syubhah, Islamic Food, Semi Processed food, Trust and Purchase behavior

\section{GENERAL INSTRUCTION}

Foods in Islam are important aspects of a Muslim's life. It has very clear dietary restrictions not only with the prescription of permissible food and drink but with the practice of consuming and decorum (Mohamed Nasir \& Pereira, 2008). Food in Islam is not just important for satisfying hunger, as well as being a source of energy and health for human life but also shaping human individuality (Man \& Yahaya, 2014). In Islam, the relationship between food, eating and individuals, families and societies is considered a matter of worshipping God, like ritual prayers (Riaz \& Chaudry, 2004). It is a comprehensive system that administrates rules and manners governing the life of every individual Muslim. Therefore, on Islam food consumption, the aspects of cleanliness, purity and everything with regard to the food consumed by the followers or Muslims are of vital concern in this religion (Mufti Department of Brunei, 2012). This aligned with what have been mentioned in the Quran the food prepared, processed and consumed by all Muslim must be halal.

Food is a dietary standard and important part of Muslims daily life which food laws carry a special significance. Muslims are expected to eat for survival, to maintain good health and not to live for eating. In Islam, eating is considered to be a matter of worship of God like prayer, fasting, arms-giving and other religious activities (Nasr, 1981). Marzuki, Collin, \& Ballantine (2012) posited that basic adherence in food by a good Muslim are; whatever food goes into the mouth will reflect to person physically, mentally and spiritually and good food delivers good mind and soul. 
In Al Quran, human beings are urged to process, prepare and consume the wholesomeness of food. This is evident based on several surahs'. However examples of versus from two different surahs are subsequently highlighted.

Surah Al-Baqarahor the Cow, verse 172

o ye who believe! Eat of the good things that we have provided for you, and be grateful to Allah, if it is Him ye worship a

Surah Al-Maidah, The Table Spread, verse 5

This day are (all) things good and pure made lawful unto you. The food of the

People of the Book is lawful unto you and yours is lawful unto them.

All these matters in addition to others are contained within the concept of halal and haram.

\section{HALAL, HARAM AND SYUBHAH}

Halal in actual fact came from the Arabic root language which means permitted, allowed, lawful licit and legitimate (Man and Yahya 2014; Dahalan, 2008; \& Kocturk, 2002)In a contradictory, haram is referred as something that unlawful and restricted by Syarak and sinful (Man and Yahya, 2014). A good Muslim are very aware on haram that show them to their abidance and filial in Islam. A strong clarification from Al Bakri (2014) translated from Yusuf Al Qaradhawi is that if the Halal and Halam are accumulated together and then Haram will win.

However, in between amenable of halal and haram there come a word of Syubhah as part of the balance of Islamic syariah rules and regulation. Syubhah is also come from the Arabic root word Syabaha which means near to, parallel, glimmer, suspected, or unclear things that suspicion and doubtful in term of halal and haram status (Man and Yahya, 2014). Mukhtar and Butt (2012) clarified syubhah as a certain condition rises which are difficult to clearly categorized whether they are halal or haram. In other words, syubhah is pronounced due to the unclear explanation or any doubtful products related to haram and halal status which need to be comprehensible by decree of fatwa (Qaradhawi, 2014). According to Man and Yahya (2014) in order to determine the amenable of syubhah, the Mujtahid need to refer the dalil-dalil in the Al Quran , sunnah, ijma' and qisas.

\section{SYUBHAH, FOOD AND CONSUMER}

Syubhah or doubtful is closely linked with doubts or suspicions on something which would cause uncertainty and constantly unsettled in mind or opinions (Ambali and Bakar, 2012). Islamic scholar Al Ghazali (2013) on his statement emphasized that syubhah on food will become wickedness if continuously being practice and consume and he therefore advised it has to be omitted and leave out by the Muslims. In a simple word, he state that a pious will leave syubhah food in their lifestyle.

However, in this era as lifestyle, businesses and economy is continuously becoming more complicated with food processes have gone beyond conventional styles through the innovation and invention, syubhah or doubtful on certain food products have become an important issue (Ambali and Bakar, 2014). This issue arises in many situations ranging from the ingredients, preparation, composition, processes, consumption or in short it relates to the whole of it supplies chain (Burhan, 2000; Zalina, 2008). They contend that science and technology lead to various improvision of the food products using the doubtful ingredients. 
With the highest market in this country, Muslim consumers are undoubtedly ascertained that the food products obtained or, buying from any market place should religiously fit for their consumption (Rahman, Ahmad, Mohamad, \& Ismail, 2011; Ambali \& Bakar, 2014). The concern relates to the halalness of the ingredients used, preparation and cleanliness of the products either on dry, wet, fresh, canned or processed (Dindyal, 2003).

\section{SEMI PROCESSED FOOD}

Semi processed food refers to food products that are produced subjected to partial processing by the manufacturer or the processors (Fortuin \& Omta, 2009). In a consumer perspective, a semi processed food is defines as a suitable product that suits the user to continue to consume with less preparation or preparation process is reduced (Ogden, Rossetti, \& Hendrick, 2007).

Semi processed food occurred when there was a changes and advances in food science and technology that enabled the communities to consumed the product throughout the year without not to worry on difficult to get due to the seasonal products, convenient and balanced diet (Berita Harian, 2014a). Semi processed foods will make a product sustain in the market to meet consumer needs (Chaudry, Jackson, Hussaini, \& Riaz, 2000) They insist that semi processed food help consumers in their daily lives by many factors such as saving time, the cooking process easier and lower cost consumption (Lim, Hui., Nip, Smith, \& Yu, 2004) differentiated the purpose of the semi processed food between modern reasons and traditional reasons. They explained that in modern reasons the process were become more rigid due to the factors of adding value to food, improving visual appeal and convenience which compared with previously traditional that only make the product to be last longer without spoiling.

In contrast, semi processed food also is labelled as contributing to the food poisoning (Berita Harian, 2014a). This statement is always been expressed in the community who feel it will harm the consumer when it is not been controlled in human consumption (International Food Information Council Foundation, 2013). Gaze, 2005 revealed that with the new added characteristic in semi processed food, it will also have effects to the body that come from the food chemicals used and which being consumed frequently. Then, it goes to the social responsibility from the manufacturer sides to control and monitor the uses of chemical and additive strictly (Mc clements, et al, 2011; International Food Information Council Foundation, 2013).

Semi processed food cannot be avoid due to changing trends and lifestyles that require consumers to find products that can simplify the process of food preparation and saves time strictly (Mc clements, et al, 2011; Chaudry, et al , 2000). Draw to this attention, this phenomenon have been further boosted by the food technology industry and food producers that strive to produce convenient foods through product innovation and new cooking methods with simple packaging to meet consumer needs (Henderson, Handy, \& Neff, 2013; Talib \& Ali, 2008). Due to the fact that the products meet the consumers need, semi processed food products have been widely marketed in groceries shop and a large supermarket or even at the small scale grocery store near the rural area (Yunus, Chik and Mohamad, 2010).

Not to exaggerate that, most of the semi processed food products are comes from large manufacturing companies that have dominated the market with perfect competition market share that offer high products life span, easy to store and convenience to used (Henderson, et al, 2013; and Yunus, Chik and Mohamad, 2010). In fact, the possession of the company's products such as cans, bottles and boxes which have a shelf life expiration date is undeniable that the products which have a long length life span can be marketed through vast market area which also reflects in penetrating to all rural areas (Marsden, Banks, \& Bristow, 2000). 
In the other side, despite the products that have a long life span, there are also semi processed food that has a short lifespan which offered by the manufacturer in a short period of selling time (Boyer \& McKinney, 2013; and Malaysia Department of Agriculture, 2011) such as fresh yellow noodle, tofu and bean curd, kue teow, fish balls, fish cakes and many others. These semi processed food products requires product offering in the form of daily or weekly manufacturing and selling fresh and fast from the date manufactured (Boyer \& McKinney, 2013; Marsden, Banks and Bristow, 2009; Department of Agriculture Malaysia, 2011). Otherwise the products will face damage due to the short period of life span. Most of these semi processed food products were marketed in the wet market for daily business sales to consumers (University of Michigan, 2009; Lanford, 2011). It is a community business based products to local community consumers (AGree, 2015; Department of Agriculture Malaysia, 2011).

\section{SYUBHAH SEMI PROCESSED FOOD IN MALAYSIA}

Local producers that produce a short lifespan product in their manufacturing business in Malaysia is classified as a local economic business or so called as the Small Medium Entrepreneur (SME Corp. Malaysia, 2012). Small Medium Entrepreneur (SME) which define by the Bank Negara Malaysia, 2013) as a micro business enterprises in the manufacturing including agro-based and others related services that relate to the manufacturing sectors which the company has full-time employees of less than 5 or with annual sales turnover less than RM250,000. This business system which has been supported intensively by the government since 1995 is for the purpose of increasing economic empowerment of local communities and the national economic growth (Law of Malaysia Act 539, 2006). Regard to this policy, many food manufacturers were getting involved in generating local food based with a chance to entering broad market segmentation (SME Corp. Malaysia, 2012)

Due to that, with the multi races and religions involved in the semi processed food in Malaysia (Kosmo, 2016) products businesses starts from the manufacturing until marketing and sales much sure that various issues arise and purposely, one of the issue is regards to the Islamic consumers concern (Yunus, et al, 2010) not to exaggerate that in order to meet customer needs, many efforts were made by the manufacturers to sustain their product for local communities market (Hamdan, et. al, 2013; (Rezai, Mohamed, \& Shamsudin, 2012). With the majority of the manufacturer comes from the non Muslim, there are a lot of doubtful things and questioned raised on the ingredients, production, storing, delivering and selling or in technical word known as product supply chain (Yunus et. al, 2010). This is because the issue of halal and haram involves complicated procedures and not just mere to hygiene only (Man and Yahya, 2014; Marzuki, et.al, 2012; Hamdan et. al, 2013).

One of the major concern in Islamic concern regards to the doubtful of ingredients that been used for the semi processed food products (Mohamed, Rezai, Shamsudin, \& Chiew, 2008); (Nasaruddin, Mel, Fuad, Jaswir, \& Hamid, 2011); Yunus et.al, 2010). The use of raw materials, chemical, animal derivatives, food coloring, food additive and others unethical practice by the manufacturer are seem to be uncontrolled due to not to exaggerate as most of the small and medium scale manufacturer are from the non-Muslims (Yunus, et. al, 2010). The uses of benzoyl peroxide in production of yellow noodle and kueteow (Jamaludin and Radzi, 2009,), animal derivatives and blood in fish ball recipe (Consumers Association of Penang, 2006), food production technologies as GMOs (Genetically Modified Organism), GMF (Genetically Modified Food) and GMA (Genetically Modified Animal) (Brown \& Funk, 2008), the used of melamine taken from animals are used as additional agents in infant milk ingredients and other semi processed foods (Ministry of Health Malaysia, 2010; Utusan Malaysia, 2008), animal gelatin in 
chocolate (Mingguan Malaysia, 2014; Berita Harian, 2014c), Lecithin which based from human hair as a food additive in a variety of foods such as bread and pizza, melamine in various food products include cereals, nuts, confectionery, chocolate and milk, the used of Glucono DeltaLactone (GDL) in Tofu and Sorbic Acid in kueteow's recipe products (Consumers Association of Penang, 2006; Malaysia Food Act, 1983)

The misused of this prohibited and control substances have occurred questionable from the Islamic consumer on human health and food hygiene (Hamdan, et.al, 2013; Tieman, Ghazali and Vorst, 2013). This dilemma is not only happening to the urban area but also involves the production and sales in rural areas (Hamdan, Isa, Abu \& Jusoff, 2013). Draw to the intention of less knowledge and information, the communities in rural area more prone to this threat in using the semi processed food products that are not safe to be consumed which blinded them through interactive packaging and fake Islamic symbols (Ambali \& Bakar, 2014; and Hashim, 2004). Regardless, in a nature, semi processed food products with a pro and contra statements from consumers view, it is still reflects to the human living as a strong relation to daily human modern food consumption (Mc clements et. al 2011). Perhaps, the raising issue on the purposes of semi food product processing been made should be seen as complementary to the consumer while using this product.

\section{Consumer knowledge}

\section{LITERATURE}

The knowledge of consumer influenced consumer purchasing decision (Hamdan et al, 2013). In order to encourage the consumer to buy, the knowledge of the consumer need to be increase as one of the strategy to reduce perceive risk (Tuu \& Olsen, 2012). Customer has to educate with more information of the product in uplifting their purchase intention. Marzuki et al (2012) highlighted that knowledge is not just needed on the information of the product but also to the dietary prohibition, religious practice and cultural values. Besides that, Muslim consumers create their acceptance of food based on the cultural belief that inherits from the generation to present (Hassan, 2011). In addressing the knowledge aspect, halal knowledge management need to be organized and implement in order to prepare the market (Yahya \& Marzuki, 2013). Based on that, further explanation on the knowledge on syubhah semi processed food is mentioned below;

\section{Composition of Ingredients}

Composition of ingredients is a substance that forms parts of the mixture (Hart, 1997) or sources of foods and seasoning used in cooking that formed to be as food mixture (Duyff, Hasler, \& Ohl, 1990). Greenfield \& Southgate, (2003) refers composition of ingredients as the process of identifying, composing, mixing and determining inclusive raw and artificial ingredients with or without chemical substances in the food through new methodology and sophisticated equipments. Each of the ingredients serves a particular function and contributes to the basic characteristic of a food product (Duyff et al, 1990).

Looking at Muslim consumer awareness, the syubhah or the doubtful on food products is not just only dealing with purity of the ingredients but its goes with the chemicals, production and technology used and elements undertaking to process the products (Nasaruddin, Mel, Fuad, Jaswir, \& Hamid, 2011). Manipulation of ingredients beyond Islamic way, the used of banned substances, chemical food as well methodology and supply chain which does not following the Islamic standard is classified inresponsibly practices (Ambali \& Bakar, 2014; Nasaruddin et,al, 2011). From this issue, the integrity of the manufacturers, retailers and food suppliers are being questioned by the Muslim consumers. Out of many, one of the doubtful food issue raised among the Malaysian Muslim consumer is involving the use of prohibited substances and 
dubious ingredients in biotechnological food processing. It relates to combining the Deoxyribonucleic acid (DNA) of animal such as from pig derivatives or other animals which not classified as can be eaten by Muslim or not been slaughtered in Islamic way in the food processing which is declared as Haram by the National Fatwa Council of Malaysia (JAKIM, 1999).

\section{Trust}

Trust is related to believing for both on emotional and logical act. Emotionally, it is where individual expose to believing that they will or not take advantage or to experience and not experience against something. According to (Sang, Sang, Seong, \& Seung, 2007), trust can be defined as follows "a relationship between at least two parties, a trustor and a trustee, and is personal in nature". The importance of trust is to reduce people anxiety (Pavlou, 2003) through interpersonal relationship from a various aspect (Lewis \& Weigert, 1985) with a personal communication skill between each others.

Trust exists when there are consumers exposed to something that occurs after ingestion of a food that is eaten. Confidence in the safety and food hygiene exist on the acceptance that the manufacturer has taken into account the ability to monitor process and control something that will harm the users. Lang \& Heasman, 2004 stated that the role of trust can influence consumers to choose products to be consumed.

The effect of trust will help consumer to receive and take advantage of new advances in food technology besides their trust on the food act rules and regulations. No doubt to mention that trust could affect consumer confidence in company integrity of producing foods that cause consumer to obtain information that is incorrect and choose products low in nutrients and unhealthy products (Bonne \& Verbeke, 2008).

\section{Consumer Purchase Behavior}

Consumer Purchase behavior reflects to many questions that look at why consumers make purchases, the factors influencing consumer purchases and changes in community factors that contribute to purchase decision making. Consumer behavior is a process of decision making and consumer action that engaged in purchasing and using products (Sarker, Bose, Palit, \& Haque, 2013). Schiffman, Kanuk, \& Wisenblit (2010) clearly define consumer behavior as a consumer displayed their behave and act to purchase the products or services which include the process of searching, purchasing, using, evaluating and disposing in order to satisfy their needs. It is the study of the process involving individual or group regards to the activity of selecting, purchasing, using or disposing of the product and services including ideas and experience in achieving consumer needs and desire (Solomon, Russell, \& Previte, 2013).

\section{DISCUSSION}

Most of the Muslim consumers are believe that food implicate them on the physical as well as spiritual. In fact, knowledge and understanding on the nitty gritty of the halal management are considered vital not only in identifying halal and haram but also in syubhah. Based on the literature reviews, the consumer knowledge on composition of ingredients create consumer's belief that will lead to certain outcomes and the evaluation of results of consumer behaviour. In other word, consumer purchased behavior is expected to be influence by trust which persuade from the knowledge on composition of ingredients to purchase the syubhah semi processed food products or vice versa. 
Intention to purchase driven by a person either has the knowledge and experience of syubhah food or not. It is relates to the element of trust that makes them to react to do something that they believed. Persons who are knowledgeable and understand the cause and effect against syubhah food and as a high Islamic practice will continue to leave and refuse to buy the doubtful product. It does not apply to consumers who have no knowledge and no firm grip on the Islamic religion, which certainly will not care about the cause and effects on themselves when using the syubhah product. Peer views and pressure from the normative side regards to the importance to refuse syubhah food will assist consumers in making the decisions. Factor influence from family, friends and relatives make the consumers tries to avoid or not to using syubhah food products. Brand and symbol can help consumers convert or continue with the intention to purchase syubhah food products. In sum, consumer behaviors are formed through their experiences and believe which antecedent from the trust and knowledge on the composition of ingredients.

Having discussed the issue, a conceptual study framework was developed based on the above conjecture. Figure 1.2 diagrammed the conceptual framework of Syubhah semi processed food composition of ingredients, Trust and Consumer purchase behaviour.

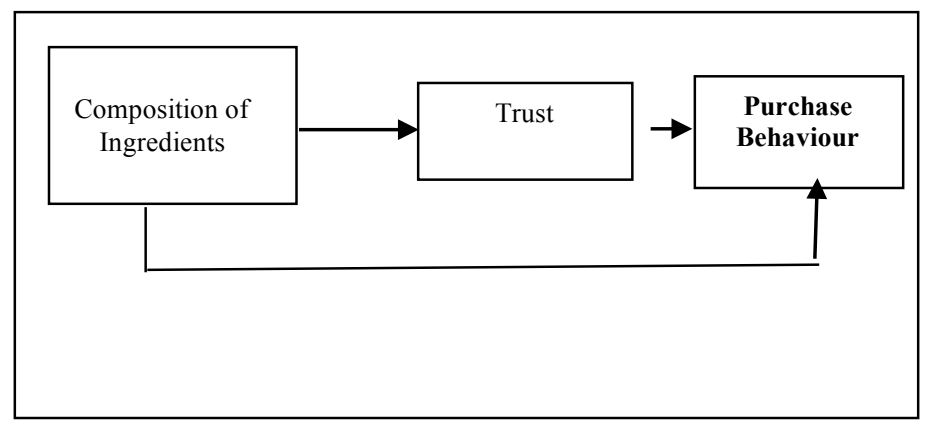

Figure 1.2: Proposed Conceptual Framework for Syubhah Semi Processed Food, Influence Others, Brand equity, Trust and Consumer Behavior

\section{CONCLUSION}

Food purchase behaviour particularly among the Muslim consumers although has long been occurring, matters related to its halalness just recently received significant attention and becoming new important subjects among the Islamic scholars in particular (Al-Hyari, Alnsour, Al-Weshah, \& Haffar, 2012; and Alam \& Sayuti, 2011). However, there is still a scarcity of available studies which look into the causal relationship between syubhah as part of food commandment in Islam and Muslim such as consumer food purchase behaviour. such as Halal certification (Marzuki et al, 2012), customer perception (Al-Nahdi, Ismail, Haron, \& Islam, 2009) and Halal logo (Muhammad, Isa, \& Kifli, 2009). In halal logistics factors, most studies focused on halal meat logistics (Tieman, Ghazali, \& Vorst, 2013)), consumer perception (Bruil, 2010)) and supply chain (Omar, Jaafar, \& Osman, 2013). In a halal food processing industry, most studies looking at the quality assurance (Talib, Ali and Jamaludin, 2008) and nutrient composition (Chaudry et.al, 2000), halal export market (Rahman et.al, 2011) and business ethical (Henderson e al, 2013)

In fact, very limited of such study is undertaken in Malaysia as multi religious and multicultural country where Syubhah in many food facets could not be avoided. Thus, the investigation on the causal relationship between knowledge of the Syubhah semi processed food in term of composition of ingredients together with trust toward Muslim consumer purchase behaviour will create new evidence and add to the existing literature consumerism studies. 


\section{Refferences}

AGree. (2015). Local Food: Revitalizing Community-based Food Systems. AGree - Transforming Food and Agriculture Policy, 1-11. AGree Publication. Retrieved from A: www.foodandagpolicy.org

Al Ghazali, I. (2013). Ihya Ulumuddin (6th ed.). (H. Isa, Ed., \& A. S. Dimisqi, Trans.) Malaysia: BukuBuku Publication. Alam, S. S., \& Sayuti, N. M. (2011). Applying the Theory of Planned Behavior (TPB) in halal food purchasing. International Journal of Commerce and Management, 21(1), 8-20.

Al-Hyari, K., Alnsour, M., Al-Weshah, G., \& Haffar, M. ( 2012). Religious beliefs and consumer behaviour: from loyalty to boycotts. Journal of Islamic Marketing, 3(2), 155-174.

Al-Nahdi, M., Ismail, I., Haron, H., \& Islam, M. (2009). Intention to patronage halal restaurants among Malaysian Muslims - an issue of halal perception",. The Global Business Summit Conference.

Ambali, A. R., \& Bakar, A. N. (2014). People's Awareness on Halal Foods and Products: Potential Issues for Policymakers. Procedia - Social and Behavioral Sciences, 121, 3-25.

Berita Harian. (24 September, 2014a). 41 pelajar SMK Sultanah Bahiyah keracunan makanan. Retrieved 24 Mei, 2016, from BH Online: http://www.bharian.com.my

Berita Harian. (2014c). Perlaksanaan Persijilan Telus, penuhi prosedur: JAKIM akui berdepan cabaran selesai isu DNA babidalam dua jenama coklat Cadbury. Kuala Lumpur: Berita Harian.

Bonne, K., \& Verbeke, W. (2008). Muslim consumer trust in halal meat status and control in Belgium. Meat science, 79(1), 113-123.

Boyer, R., \& McKinney, J. (2013). Food Storage Guidelines For Consumers. Virginia Cooperative Extension programs and employment. Virginia State. Retrieved from www.ext.vt.edu

Brown, M. E., \& Funk, C. C. (2008). Food Security Under Climate Change. Science (NASA), 580-581 .

Bruil, R. (2010). Halal Logistics and The Impact Of Consumer Perception. . 1-75. University of Twente. Netherland: University of Twente.

Burhan, A. (2000). Consumer behavior and religiosity of Muslim community in Klang Valley: Consumer perception on halal and non halal in products and services. University Malaya.

Chaudry, M. M., Jackson, M. A., Hussaini, M. M., \& Riaz, M. N. (2000). Halal Industrial Production Standards. (4th ed.). Illinois, USA: J\&M Food Products Company.

Consumers Association of Penang. (2006). Guide Association of Users Penang: Halal Haram, Penang:. The Consumers Penang.

Dahalan, Z. (2008). Kecenderungan umat Islam terhadap konsep pemakanan halal: Kajian di UiTM Pulau Pinang. ECER Regional Conference. Kelantan.

Dindyal, S. (2003). How personal factors, including culture and ethnicity, affect the choices and selection of food we make. Journal of Third World Medicine, 1(22), 27-33.

Duyff, R. L., Hasler, D., \& Ohl, S. S. (1990). Modern Meals. Oklahoma : McGraw Hill.

Fortuin, F. T., \& Omta, S. (. (2009). Innovation drivers and barriers in food processing. British Food Journal, 111(8), 839-851.

Gaze, J. (2005). Microbiological aspects of thermally processed foods. Journal of Applied Microbiology, 98, 13811386. doi:10.1111/j.1365-2672.2005.02636.x

Greenfield, H., \& Southgate, D. (2003). Food Composition Data. Food and Agriculture Organization of the United Nations. Rome: Elsevier Science Publishers.

Hart, B. (1997). Technology and food production . Nutrition \& Food Science, 97 (2), 53 - 57.

Hashim, P. (2004). Food Hygiene Awareness for Food Business. Standard \& Quality News, 11, pp. 6-7.

Hassan, S. H. (2011). Consumption of functional food model for Malay Muslims in Malaysia. Journal of Islamic Marketing, 2(2), 104-124.

Henderson, D., Handy, C. R., \& Neff, S. (2013). Globalization of the Processed Foods Market - Agricultural economic Report. Washington: The United States Department of Agriculture (USDA). 
International Food Information Council Foundation. (2013). Food \& Health survey 2013 : Consumer Attitudes Toward Food Safety, Nutrition \& Health. International Food Information Council Foundation.

JAKIM. (1999). e-Fatwa JAKIM. Retrieved 2015, from Jabatan Kemajuan Islam Malaysia: http://www.efatwa.gov.my/kod-isu-tagging/1999

Jamaludin, M. A., \& Wan Mohamed Radzi, C. W. (2009). Teori Istihalah Menurut Perspektif Islam Dan Sains: Aplikasi Terhadap Beberapa Penghasilan Produk Makanan. Shariah Journal ), 17(1), 169-194.

Junus, L. (March, 2007). Sains dan Teknologi Makanan. Estidotmy - Teknologi Makanan, 61, 4-5. Ministry of Science, Technology and Inovation, Malaysia.

Kajale, D. B., \& Becker, T. C. (2013). Determinants of consumer support for mandatory labeling of genetically modified food in India: A student survey. British Food Journal, 115, 1597-1611.

Kelman, H. (2006). Interests, relationships, identities: Three central issues for individuals and groups in negotiating their social environment. Annual Review of Psychology., 57, 1-26.

Kocturk, T. O. (2002). Food rules in the Koran. Scandinavian Journal of Nutrition, 46(3), 137-139.

Kosmo. $(31$ 5, 2016). Perencah Nestle - Lebih cepat, mudah. Online. Kuala Lumpur, Malaysia.

Kotler, P., \& Keller, K. L. (2016). Marketing Management, Global Edition (15 ed.). Pearson.

Kyaw, D. (2009). Rural Households' Food Security and Coping Strategies to Food Insecurity in Myanmar. Institute of Developing Economy, Japan External Trade Organization. Japan: Institute of Developing Economy, Japan External Trade Organization.

Lanford, B. $(07,2011)$. Local Food: Does It Matter What We Eat? ECONOMIC and Community Development. Retrieved from www.clemson.edu/extension/community

Lang, T., \& Heasman, M. (2004). Food Wars: The global battle for mouths, minds and markets. London:: Earthscan.

Law of Malaysia Act 539. (2006). Small and Medium Industries Development Corporation Act 1995. Kuala Lumpur, Malaysia: Percetakan Nasional Malaysia Bhd.

Lewis, J., \& Weigert, A. (1985). Trust as a social reality. Social Forces, 63(4), 67-85.

Lim, M., Hui., Nip, W.-K., Smith, J. S., \& Yu, P. H. (2004). Principles of Food Processing. In J. S. Smith, \& Y. H. Hui, Food Processing : Principles and Applications (pp. 3-29). Iowa, USA: Blackwell Publishing.

Malaysia Food Act. (1983). Food Act 1983 \& Food Regulation 1985. Law of Malaysia. Government of Malaysia.

Malaysia, D. o. (2011). National Agro-Food Policy 2011-2020. Kuala Lumpur, Malaysia: Department of Agriculture, Malaysia;.

Man, S., \& Yahaya, Z. A. (2014). Halalkan Makanan Kita. Selangor: PTS Islamika Sdn Bhd.

Marsden, T., Banks, J., \& Bristow, G. (2000). Food Supply Chain Approaches: Exploring Their Role in Rural Development. Sociologia Ruralis, 40, 424-438.

Marzuki, S. Z., Collin, M. H., \& Ballantine, P. W. (2012). Restaurant Manager and Halal Certification in Malaysia. Journal of Foodservice Business Research, 15(2), 195-214.

Mc clements, D. J., Vega, C., \& Mc bride, A. E. (2011). In Defense of Food Science. Gastronomica: The Journal of Food and Culture, vol.11(2), pp.76-84.

Mingguan Malaysia. (2014). Analisis Polenik DNA Babi. Kuala lUmpur: Mingguan Malaysia.

Ministry of Health Malaysia. (2010). Status "Melamine Rumours" In Milk. Kuala LUmpur: Ministry of Health, Malaysia.

Mohamed Nasir, K., \& Pereira, A. A. (2008). Defensive dining: Notes on the public dining experiences in Singapore. Contemporary Islam, 2, pp. 10-13.

Mohamed, Z., Rezai, G., Shamsudin, M. N., \& Chiew, F. E. (2008). Halal logo and consumers' confidence: What are the important factors? Economic and Technology Management Review., 3, 37-45.

Mufti Department of Brunei, B. (2012). Isu-Isu produk Halal. Brunei: Al Hidayah House of Publisher Sdn Bhd.

Muhammad, N. M., Isa, M. F., \& Kifli, C. B. (2009). Positioning Malaysia as Halal-Hub : Integration Role of Supply Chain Strategy and Halal Assurance System. Asian Social Science, 5(7), 44-52.

Mukhtar, A., \& Butt, M. M. (2012). Intention to choose Halal products: the role of religiosity. Journal of Islamic Marketing, 3(2), 108-120. 
Nasaruddin, R. R., Mel, M., Fuad, F., Jaswir, I., \& Hamid, H. A. (2011). The Importance of a Standardized Islamic Manufacturing ( IMP) for Food and Pharmaceutical Productions. 2nd International Conference on Professional Ethics \& Education in Engineering 2011, (pp. 978-983). Kuala Lumpur.

Nasr, S. H. (1981). Islamic life and thought. Albany, New Yolk: State University Of New York Press.

Ogden, J., Rossetti, C., \& Hendrick, T. (2007). An exploratory cross-country comparison of strategic purchasing. Journal of Purchasing \& SupplyManagement, 13(1), 2-16.

Omar, E. N., Jaafar, H. S., \& Osman, M. R. (2013). Halalan Toyyiban Supply Chain of the Food Industry. Journal of Emerging Economies and Islamic Research, 3, 1-12.

Pavlou, P. (2003). Consumer acceptance of electronic commerce: integrating trust and risk with the technology acceptance model. International Journal of Electronic Commerce , 7(3), 101-134.

Qaradhawi, Y. A. (2014). Halal dan Haram dalam Islam (3rd ed.). (Z. M. Bakri, Trans.) Negeri Sembilan: Pustaka Cahaya Kasturi Sdn Bhd.

Rahman, A. H., Ahmad, W. I., Mohamad, Y., \& Ismail, M. Z. (2011). Knowledge on Halal Food amongst Food Industry Entrepreneurs in Malaysia. Asian Social Science, 7(12), 216-222.

Riaz, M. N., \& Chaudry, M. M. (2004). Halal Food Production. Boca Raton, Florida: CRC Press.

Sang, M. L., Sang, H. P., Seong, N. Y., \& Seung, J. Y. (2007). RFID based ubiquitous commerce and consumer trust. Industrial Management \& Data Systems, 107(5), 605-607.

Sarker, S., Bose, T. K., Palit, M., \& Haque, M. E. (2013). Influence of personality in buying consumer goods-a comparative study between neo-Freudian theories andtrait theory based on Khulna region. International Journal of Business and Economics Research, 2(3), 41-58.

SME Corp. Malaysia. (2012). Summary SME Master Plan 2012-2020 : Catalyst Growth and Income. SME Corp. Malaysia. Kuala Lumpur, Malaysia: SME Corporation Malaysia.

Solomon, M. R., Russell, B. R., \& Previte, J. (2013). Consumer behaviour : Buying, having, being. Australia: Pearson Eduction Inc.

Talib, H. H., \& Ali, K. A. (2008). Aspek Kualiti, Keselamatan Dan Kesihatan Di Kalangan Pks Makanan: Satu Sorotan Kajian. Jurnal Teknologi, 49, 65-79.

Talib, H. H., Ali, K. A., \& Jamaludin, K. R. (2008). Quality Assurance in Halal Food Manufacturing in Ma.

International Conference on Mechanical and \& Manufacturing Engineering (ICME2008),. Johor: Universiti Tun Hussein Onn Malaysia.

Tieman, M., Ghazali, M. C., \& Vorst, J. G. (2013). Consumer perception on halal meat logistics. British Food Journal, 115(8), 1112-1129.

Tuu, H. H., \& Olsen, S. O. (2012). Certainty, risk and knowledge in the satisfaction-purchase intention relationship in a new product experiment. Asia Pacific Journal of Marketing and Logistics, 24(1), 78-101.

University of Michigan. (2009). Building a Community-Based Sustainable Food System. University of Michigan, Urban \& Regional Planning, Michigan USA.

Yahya, W., \& Marzuki, S. (2013). Revitalishing Halal Market Potential Through Islamic Business Practices: The Futue of HAlal Business. The Emergence of Global Halal Business, 135-138. UiTM Press.

Yunus, M., Wan Chik, W., \& Mohamad, M. (2010). The Concept of Halalan Tayyiba and Its Application in Products Marketing : A Case Study at Sabasun HyperRuncit Kuala Terengganu, Malaysia. International Journal of Business and Social Science, 1(3), 239-248.

Zalina, Z. (2008). Topping into world Halal Market: Some Discussions on Malaysia Laws and Standards : . Journal of Syariah, 16, $603-616$. 